known, the only institution in Britain at present offering training facilities is the Kodak School of Engineering Radiography, Wealdstone, Harrow, Middlesex. Advice on the use of gamma-radiography (demonstrations are given) may be obtained from the Superintendent of Radiology Research, Ministry of Supply, Armament Research Establishment, Woolwich, London, S.E.18, and also from the Director, Natipnal Physical Laboratory, Teddington, Middlesex.

\section{Gasteromycetes of Geenland}

MORTEN IANGEthas published a critical survey of the Gasteronivetes found in Greenland prior to the expeditivn of 1946 (Medd. Gronland, 147, No. 4, pp. $32+1$ pl. Kobenhavn: C. A. Reitzels Forlag, 1948. KI 2.00). Thirteen species are described in do! sl. Most of them have European or North American affinities, though Calvatia tatrensis var. groenlandica is practically confined to Greenland. Some earlier records are reviewed, and their naming compared with modern standards.

\section{University of Birmingham : Appointments}

THE following announcements have been recently made in the Uhiversity of Birmingham. The title of reader in onal physiology has been conferred on J. A. Barclgy, lecturer in physiology. Appointments : F. J. Dyon to be research fellow in mathematical physics/, J. T. Allanson to be lecturer in electrical enginfering; B. H. Pethica to be lecturer in pharmacolggy; R. J. Boscott to be lecturer in endocrine chbmistry. Resignations: Dr. H. B. Whittington, lecturer in geology, on appointment as visiting lecturer in geology at Harvard University; C. D. Cruikshank, lecturer in bacteriology, on appointment as assistant pathologist at the Selly Oak Hospital; $\mathrm{S}$. Harper, lecturer in metallurgy, on appointment as research fellow at the University of Chicago; M. A. Preston, assistant lecturer in mathematical physics, on appointment as assistant professor in the Department of Physics, University of Toronto; P. L. Adams, lecturer in mining, on appointment as senior lecturer in charge of mining in the University of Sydney; S. R. Cornick, a member of the physics technical staff for thirty years and steward of the Department since 1937, on appointment as chief technical officer to the Australian National University at Canberra.

\section{Institute of Metals}

THE Institute Mietals has appointed the following to be honoray corresponding members for their respective coantries : Spain, Prof. J. Orland, professor and hief of the Department of Metallography and Strepgth of Materials, Instituto Católico de Artes o Industrias, Madrid; Sweden, Prof. A. G. E. Hultgren professor of metallography, Tekniska Högskolan, Stockholm ; United States, Prof. R. F. Mehl, director of the Metals Research Laboratory and head of the Department of Metallurgical Engineering, Carnegie Institute of Technology, Pittsburgh, and Dr. R. A. Wilkins, vice-president (research and development), Revere Copper and Brass, Inc., Rome, N.Y.

\section{Royal Aeropautical Society}

THE Coymcil of the Royal Aeronautical Society for the year 1949-50 has been announced as follows: Presideht, Sir John S. Buchanan; Past Presidents, Dr. H. Roxbee Cox, Sir Frederick Handley Page; Vice-Presidents, Mr. W. G. A. Perring, Mr. N. E.
Rowe, Dr. H. C. Watts ; Council Members, Lord Brabazon of Tara, Major G. P. Bulman, Mr. S. Camm, Mr. A. V. Cleaver, Dr. G. P. Douglas, Mr. G. R. Edwards, Mr. A. G. Elliott, Mir. W. S. Farren, Sir A. H. Roy Fedden, Sir Arthur Gouge, Major F. B. Halford, Prof. A. A. Hall, Mr. S. Scott Hall, Mr. J. W. F. Housego, Mir. P. G. Masefield, Mr. W. Tye, Capt. C. F. Uwins ; Honorary Librarian, Mr J. E. Hodgson; Honorary Treasurer, Capt. C. F. Uwins; Solicitor, Mr. L. A. Wingfield; Secretary, Capt. J. Laurence Pritchard.

\section{Announcements}

Prof. H. P. Himsworth has been appointed by the Medical Research Council to be its secretary in succession to SIr Edward Mellanby, who retires on October 1. Dr. Himsworth is at present professor of medicine In the University of London and director of the Aredical Unit at University College Hospital; he has been a member of the Council since February 1948.

THE Thomas Young Oration for 1949 of the Physical Society will be delivered by Mr. T. Smith on Jyne 10 ; he will take as his subject "The Contribations of Thomas Young to Geometrical Optics, and their Application to Present-day Questions"

THE Royal Astronomical Society is arranging meetings to be held during June 30-July 2 in Manchester, in 6-operation with the University of Manchester and the Manchester Astronomical Society. The programme includes a public lecture at the University, to be given by Dr. M. A. Ellison, of the Royal Observatory, Edinburgh, on "Sun, Radio and the Stars", on June 30 ; a visit to Jodrell Bank Experimental Station on the morning of July 1, followed bv an ordinary meeting of the Royal Astro. nomical Society, and a dinner given by the Vice. Chancellor of the University; and a Geophysical Discussion on "Ionization in the Earth's Upper Atmosphere", to be held on July 2. Further inform. ation can be obtained from the Assistant Secretary, Royal Astronomical Society, Burlington House, London, W.1.

A cgNFERENCE on "The Properties of SemiCondycting Materials" is to be held at the Universty of Reading during July 11-14, 1950. The onference will be sponsored by the International Union of Physics, in co-operation with the Council of the Royal Society. It is hoped that papers will be read by prominent representatives from the United States and European countries. Details will be published later.

THE Royal Aeronautical Society announces that a scholarsy p to be known as the Royal Aeronautical Society Charter Scholarship, up to the value of $£ 300$ a yoar, will be awarded annually to assist a student wishing to undertake advanced work or study in aeronautics. Normally, the work should lead to a higher degree or postgraduate diploma, although this is not essential. Scholarships will in the first instance be awarded for a period of one year. Applications should reach the Secretary of the Society not later than June 30, stating the course it is intended to follow.

Errajom. In Nature of May 28, p. 833, it was stated/hat a summer school on electron microscopy will be held at the Cavendish Laboratory, Cam. blage; the dates for this school are August 16-27. 